\title{
SICKNESS RATE AND PREVALENCE OF THYROID CANCER IN A SPECIFIC REGION OF UKRAINE 30 YEARS AFTER CHERNOBYL DISASTER
}

\section{CZĘTTOTLIWOŚĆ ZACHOROWAŃ I ROZPOWSZECHNIENIE SIE RAKA TARCZYCY W SZCZEGÓLNYM REGIONIE UKRAINY 30 LAT PO KATASTROFIE W CZARNOBYLU}

\author{
Oleksandr Oliynyk ${ }^{1(\mathrm{~A}, \mathrm{~B}, \mathrm{C}, \mathrm{D}, \mathrm{F}, \mathrm{F})}$, Anna Ślifirczyk ${ }^{2(\mathrm{D}, \mathrm{E})}$, Tatiana Potupalova ${ }^{1(\mathrm{~A})}$, \\ Volodymyr Slobodian ${ }^{1(\mathrm{~A})}$
}

${ }^{1}$ I. Horbachevsky Ternopil State Medical University, Ukraine

${ }^{2}$ Pope John Paul II State School of Higher Education in Biala Podlaska, Poland

Authors' contribution Wkład autorów:

A. Study design/planning zaplanowanie badań

B. Data collection/entry zebranie danych

C. Data analysis/statistics dane - analiza i statystyki D. Data interpretation interpretacja danych E. Preparation of manuscript przygotowanie artykułu F. Literature analysis/search wyszukiwanie i analiza literatury G. Funds collection zebranie funduszy

\section{Summary}

Background. The study aimed to determine the effect of iodine deficiency and increased radiation on morbidity of thyroid cancer in patients living in the Ternopil region of Ukraine. The task was solved by comparing the patients with thyroid cancer from the district areas with iodine deficiency and increased radiation with those coming from the regions with normal iodine content and a normal radioactive background.

Material and methods. The area of the Ternopil region was divided into the following 1) the northern area, with sufficient iodine content in food, radiation background $-0.09 \mathrm{mcSv} / \mathrm{h} ; 2$ ) the central and western areas, endemic in terms of iodine content and increased background radiation (up to $0.13 \mathrm{mcSv} / \mathrm{h}$ ); and 3 ) the southern area, with sufficient iodine but increased background radiation (up to $0.15 \mathrm{mcSv} / \mathrm{h}$ ). To conduct the analysis and determine the sickness rate, the patients were grouped depending on sex and age.

Results. The sickness rate and prevalence of thyroid cancer in males in 2016 were 4-6 times lower when compared to females in all areas. The sickness rate of the females in the areas with increased radiation turned out to be age-dependent with a 1.25-3.2 times increase when compared to the areas with normal conditions. In the areas of the increased background radiation and dietary iodine insufficiency, the sickness rate of females was 1.54-5.4 times higher than the index in the areas with normal conditions.

Conclusions. The highest rates prevalence and sickness rate of thyroid cancer in Ternopil region of Ukraine were observed in women over 51 years. The prevalence was 2 times, and the sickness rate 3 times higher in women over 51 years in the areas with iodine deficiency and an increased radiation background when compared to those in the areas with normal iodine and radiation background.

Keywords: thyroid cancer, morbidity, Ukraine, the Ternopil region

\section{Streszczenie}

Wprowadzenie. Celem pracy było określenie wpływu niedoboru jodu i zwiększonej radiacji na zachorowalność na raka tarczycy pacjentów mieszkających w ukraińskim obwodzie tarnopolskim. Porównano grupe pacjentów chorujacych na nowotwory tarczycy pochodzaca z obszarów, gdzie stwierdzono niedobór jodu i zwiększone promieniowanie z pacjentami, z grupą u których stwierdzono tę samą chorobę, ale pochodzą z regionów o normalnej zawartości jodu i normalnym promieniowaniu radioaktywnym.

Materiał i metody. Obwód tarnopolski został podzielony na następujące sfery: 1) północną, z wystarczającą ilością jodu w żywności oraz promieniowaniem - 0,09 mcSv / h; 2) centralną i zachodnią, endemiczną pod względem zawartości jodu oraz zwiększonym promieniowaniem (do 0,13 mcSv / h); oraz 3) południową, z wystarczającą ilością jodu, ale zwiększonym promieniowaniem (do 0,15 mcSv / h). Aby przeanalizować częstotliwość występowania choroby, pacjentów pogrupowano w zależności od płci i wieku.

Wyniki. W 2016 r. wskaźnik zachorowalności i częstość występowania raka tarczycy u mężczyzn był 4-6 razy niższy niż u kobiet we wszystkich badanych obszarach. Wskaźnik zachorowalności u kobiet na obszarach o podwyższonym promieniowaniu skutkował średnim wzrostem, w zależności od wieku, tj. o 1,25-3,2, w stosunku do osób pochodzących z obszarów nienapromieniowanych. Na terenach zwiększonego promieniowania i niedoboru jodu wskaźnik zachorowalności u kobiet był 1,54-5,4 razy wyższy od spotykanego na obszarach nieskażonych.

Wnioski. Najwyższe wskaźniki zachorowalności na raka tarczycy w tym regionie Ukrainy zaobserwowano u kobiet powyżej 51 roku życia. Częstotliwość występowania raka na obszarach z niedoborem jodu i zwiększonym promieniowaniem była 2 razy większa, a liczba zachorowań 3 razy większa, niż u kobiet pochodzących z obszarów o normalnym poziomie jodu i promieniowania.

Słowa kluczowe: rak tarczycy, zachorowalność, Ukraina, obwód tarnopolski
Tables: 1
Figures: 1

References: 11

Submitted: 2017 Jul 26

Accepted: 2018 Jan 19

Oliynyk 0, Ślifirczyk A, Potupalova TO, Slobodian VV. Sickness rate and prevalence of thyroid cancer in a specific region of Ukraine 30 years after Chernobyl disaster. Health Prob Civil. 2018; 12(1): 29-32. https://doi.org/10.5114/hpc.2018.74187

Address for correspondence / Adres korespondencyjny: Oleksandr V. Oliynyk, I. Horbachevsky Ternopil State Medical University, m.Voli, 1, Ternopil, 46001, Ukraine, e-mail: alexanderoliynyk8@gmail.com, phone: +380 352524492

Copyright: (C) Pope John Paul II State School of Higher Education in Biała Podlaska, Oleksandr Oliynyk, Anna Ślifirczyk, T.O. Potupalova, V.V. Slobodian. This is an Open Access journal, all articles are distributed under the terms of the Creative Commons Attribution-NonCommercial-ShareAlike 4.0 International (CC BY-NC-SA 4.0) License (http://creativecommons.org/licenses/by-nc-sa/4.0/), allowing third parties to copy and redistribute the material in any medium or format and to remix, transform, and build upon the material, provided the original work is properly cited and states its license. 


\section{Introduction}

Due to the focused attention of healthcare bodies and the public, the prevalence of thyroid cancer has been recorded reliably since the Chernobyl disaster. In the authors' judgment, family doctors, particularly those working in the rural areas, should be alerted to the issue. This may contribute to early diagnosis and, thereafter, better treatment outcome.

As far back as 1976, thyroid cancer was regarded as an uncommon disease and was rated as "other tumours" [1] in the statistical bulletins of the Ministry of Public Health of the then USSR. Radiation is known to be a strong causative factor of thyroid cancer morbidity. The amount of iodine, consumed with food, is also reported to take effect. The objective of the research work is to compare the role of various factors in the pathogenesis of thyroid cancer. For this purpose, the number of thyroid cancer cases in the Ternopil region were analysed. The specificity of the territory is that some areas are endemic in terms of iodine content, some exhibit increased background radiation, while others are normal both in iodine content and radiation level.

\section{Material and methods}

The data from the Ukrainian National Cancer Register on the Ternopil region in 2016 were used in the analysis [2]. The areas were grouped as follows 1) the northern one, with a sufficient iodine content in food, radiation background $-0.09 \mathrm{mcSv} / \mathrm{h} ; 2$ ) the central and western areas, endemic in terms of iodine content and increased background radiation (up to $0.13 \mathrm{mcSv} / \mathrm{h}$ ); and 3) the southernarea, with normal amount of iodine but increased background radiation (up to $0.15 \mathrm{mcSv} / \mathrm{h}$ ) [3]. To conduct the sickness rate analysis, the patients were grouped depending on sex and age. There were fewer males and the sickness rate in some groups was less than 1 percent. All the men were pooled in a single group. The Pearson $\chi 2$ test was applied for establishing index difference reliability. The Pearson $\chi 2$ test is a nonparametric method, commonly used for evaluating significant differences between the actual qualitative characteristic of sampling in each category, and merely theoretical quantity which might be expected in test groups, provided that the null hypothesis is correct. The method allows assessing the statistical significance of differences between 2 or more relative indices. The $\chi 2$ test is used in analysing contingency tables, containing information on the occurrence frequency, depending on the presence of the risk factor.

To determine the statistical significance of differences between the thyroid cancer sickness rate and the prevalence of the disease in different areas, we calculated the Pearson $\chi 2$ criterion and compared it with the critical value. In case the Pearson $\chi 2$ test value surpassed the critical one, a statistical interrelation of the studied risk factor and the result was concluded, and the level of significance taken into account.

The criterion calculated value having been determined, the Pearson $\chi 2$ test critical value was found and recorded in the table. The value amounted to 3.841 (significance level $p=0.05$ and degree of freedom 1).

\section{Results and discussion}

The sickness rate and prevalence of thyroid cancer in males in 2016 were found to be 4-7 times lower in all the areas when compared to females (Table 1.). No reliable difference between different age groups was found that could be attributed to an insignificant sickness rate. Therefore, the sickness rate and prevalence in all male age groups were determined in a single group (Fig.1).

Table 1. Sickness rate and prevalence of thyroid cancer in the areas of Ternopil region of Ukraine depending on the content of iodine and the radiation background level in 2016

\begin{tabular}{|c|c|c|c|c|c|c|}
\hline \multirow{3}{*}{$\begin{array}{l}\text { Sex, } \\
\text { age }\end{array}$} & \multicolumn{2}{|c|}{$\begin{array}{l}\text { Areas with decreased iodine } \\
\text { content and increased radia- } \\
\text { tion background }\end{array}$} & \multicolumn{2}{|c|}{$\begin{array}{l}\text { Areas with increased radia- } \\
\text { tion background }\end{array}$} & \multicolumn{2}{|c|}{$\begin{array}{l}\text { Areas with normal iodine } \\
\text { content and radiation back- } \\
\text { ground }\end{array}$} \\
\hline & Prevalence & Sickness rate & Prevalence & Sickness rate & Prevalence & Sickness rate \\
\hline & \multicolumn{2}{|c|}{ Per 1000000 population } & \multicolumn{2}{|c|}{ Per 1000000 population } & \multicolumn{2}{|c|}{ Per 1000000 population } \\
\hline Females, $18-25$ years & 25.9 & 4.2 & 23.9 & $2.9^{*}$ & $7.5^{*}$ & $0.9^{*}$ \\
\hline Females, $26-40$ years & 31.0 & 4.8 & 32.1 & 3.9 & 26.4 & $3.1^{*}$ \\
\hline Females, $41-50$ years & 69.2 & 9.7 & 50.2 & $6.1^{*}$ & $35.8^{*}$ & $4.4^{*}$ \\
\hline $\begin{array}{c}\text { Females, older than } \\
\text { 51years }\end{array}$ & 75.3 & 10.4 & $46.6^{*}$ & $5.8^{*}$ & $28.3^{*}$ & $4.6^{*}$ \\
\hline
\end{tabular}




\begin{tabular}{|c|c|c|c|c|c|c|}
\hline $\begin{array}{c}\text { Males, } 18 \text { years and } \\
\text { older }\end{array}$ & 7.3 & 1.1 & 9.5 & 1.1 & $5.5^{*}$ & $0.7^{*}$ \\
\hline mean value & 32.1 & 6.0 & 26.6 & $3.3^{*}$ & $16.9^{*}$ & $2.1^{*}$ \\
\hline
\end{tabular}

*- reliable result difference $(\mathrm{P}<0.05)$ as to the corresponding index in the area with decreased iodine content and increased radiation background

In the Ternopil region, the sickness rate and prevalence of thyroid cancer in females are lower than in Ukraine on the whole [4] and the USA [5, 6], but higher as compared to the indices in Europe [7, 8].

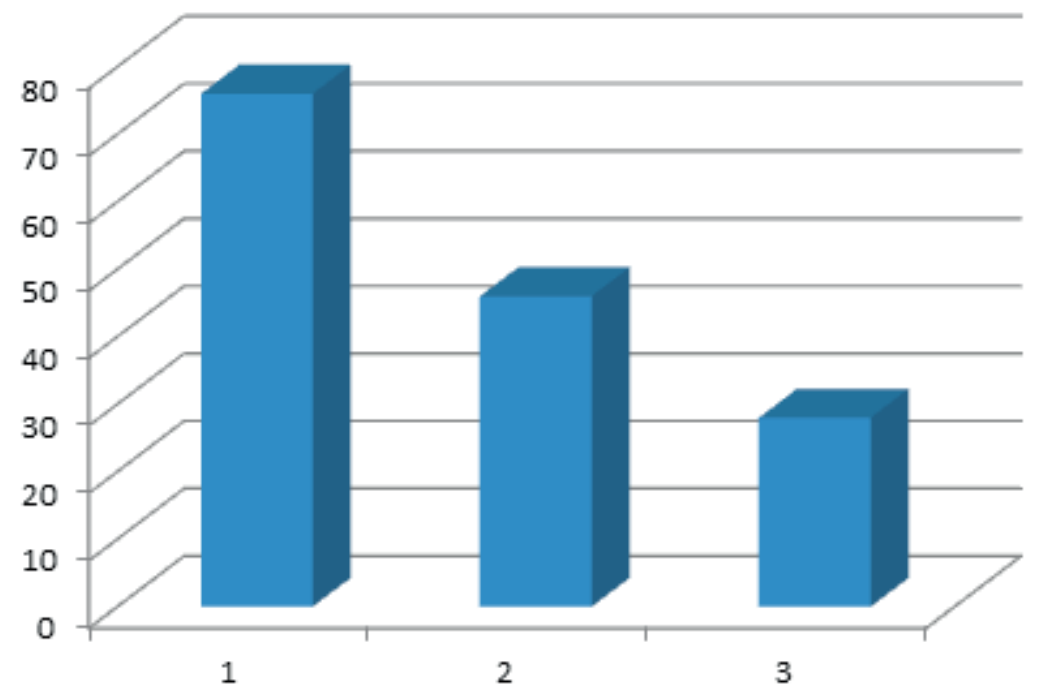

Figure 1. Prevalence of thyroid cancer in women over 51 years old in the areas with decreased iodine content and increased radiation background (1), increased radiation background (2) and normal iodine content and increased radiation background (3)

Our findings confirm the other research data which indicate that thyroid cancer occurs 3-10 times more often in females when compared to males [4]. According to the Ukrainian National Cancer Register [2], in 2009 thyroid cancer was diagnosed in Ukraine in 2267 persons (420 males and 1847 females, i.e. 18 and 81 percent respectively). Besides, the highest morbidity indices were noted in females in the age range 45-69 years. In the Ternopil region, the highest sickness rate was observed in females above 51 years. The mean value of morbidity in Russia [9] was 4 percent, whereas in Ukraine it amounted to 6 percent in the areas of increased radioactive background and insufficient iodine content; only 3.3 percent in the areas with increased radioactive background; and 2.1 percent in the areas with normal radioactive background and sufficient dietary iodine content. Obviously, age-dependant morbidity in the areas of the Ternopil region with the increased radioactive background is on average 1.25-3.2 times the index of the sickness rate in the areas with normal conditions. In the areas with increased radioactive background and insufficient food iodine content, the sickness rate is on average 1.54-5.4 times the index in normal areas.

The thyroid cancer morbidity index largely depends on the settlement area. Age-adjusted morbidity index (2008) in the USA was 6.8 new cases per 100,000 population, with females revealing higher sickness rate [6]. The highest index was noted in Hawaii (119 for females and 45 for males). The lowest registered morbidity index equalled to 1.4 per 100000 females and 0.4 per 100,000 males. In Europe, mean thyroid cancer morbidity index is $1.2-3$ per 100,000 population, the lowest values being found in the Netherlands, Slovakia and Denmark [9]. The residents of New Caledonia reveal high index - 80.9 per 100,000 population. In Russia, thyroid cancer morbidity index in 1995 was 1.1 for males and 4.0 - for females per 100,000 populations, while in $2002-1.4$ and 7.2, respectively [10]. Within the period 1990-2010, the indices in Sankt-Petersburg were 3.5-6.7 for females and 1.4-2.2 - for males (per 100,000 population). These data may indicate that thyroid cancer development depends on the environment and ethnic (genetic) risk factors. For instance, the risk of thyroid cancer development has been found to be 10 times higher in the relatives of patients with thyroid cancer [9].

The indices of thyroid cancer prevalence in the Ternopil region in 2016 correlate with the sickness rate indices in different age groups, with both indices increasing with ageing. Thyroid cancer is more common 
in females. However, prevalence indices are lower here than on average in Ukraine and in the world as such. According to the Connecticut register (USA) [11], thyroid cancer prevalence in the USA is 67.7 cases per 100,000 population for females and 23.7 cases - for males. The highest thyroid cancer prevalence in the Ternopil region is 32 cases for females and 6 cases for males (per 100.000 population). This can be attributed to the fact that the patients do not report to the oncologist and, therefore, are usually overlooked by the medics. There are just a few main reasons for avoiding examination: primarily, irresponsibility and reluctance to undergo treatment, often due to the lack of funds; and secondly, common lethal outcome. Nevertheless, in the authors' judgment, 30 years after the Chernobyl disaster, the Ternopil region reveals similar and even lower indices of thyroid cancer sickness rate and prevalence as compared with those in Europe and the USA. The catastrophe gave rise to a number of extremely pessimistic predictions as to the increase of thyroid cancer sickness rate in Ukraine, which, fortunately, proved to be grossly exaggerated. A possible explanation is that, from the ecological standpoint, the Ternopil region is regarded as the cleanest in Ukraine.

Radiation is considered to be the only factor which causes thyroid cancer. However, our findings show that dietary iodine insufficiency appreciably contributes to the effect of the increased radioactive background. This may be attributed to the fact that increasing the contact area of thyroid cells and blood under absolute or relative iodine insufficiency is a basic mechanism of developing thyroid tissue hyperplasia. Iodine insufficiency may lead to a constant stimulation of the thyroid tissue due to the increased content of thyroid-stimulating hormone (TSH). Our findings suggest that the iodine insufficiency factor may be coupled with the radiation effect.

\section{Conclusions}

30 years after Chernobyl disaster, in 2016, the Ternopil region, partly stricken by the accident, reveals similar and even lower indices of thyroid cancer sickness rate and prevalence, as compared with those in Europe and the USA.

The highest prevalence and sickness rate of thyroid cancer were observed in women over 51 years. The incidence was 2 times, and the sickness rate 3 times higher in women over 51 years in the areas with iodine deficiency and an increased radiation background compared to those in areas with normal iodine and radiation background.

\section{References:}

1. Larin OS, Cherenko SM. Diagnostic and treatment of thyroid cancer. Kyiv: Zdorovja; 2011 (in Ukrainian).

2. National Cancer Register of Ukraine [cited 2017 Dec 02]. Available from: http://www.ncru.inf.ua.

3. terses.gov.ua/.../538-radiatsiinyi-fon-na-terytorii [cited 2017 Dec 02].

4. Rybakov SI. Thyroid carcinoma: clinical lectures. Poltava: ACMI; 2012 (in Ukrainian).

5. Deen MH, Burke KM. Cancers of the Thyroid: Overview and Statistics in the United States and Oklahoma. J Okla State Med Assoc. 2016; 109(7-8): 333-8.

6. Zamoiski RD, Cahoon EK, Freedman DM. Prospective study of ultraviolet radiation exposure and thyroid cancer risk in the United States. Cancer Epidemiol Biomarkers Prev. 2016; 12: 356-4. https://doi.org/10.1158/1055-9965.EPI-16-0739

7. Megwalu UC, Saini AT. Racial disparities in papillary thyroid microcarcinoma survival. J Laryngol Otol. 2017 Jan;131(1):83-87. https://doi.org/10.1017/S0022215116009737

8. Zhou P, Tian S, Li J, Zhao Y. Paradoxes in thyroid carcinoma treatment: analysis of the SEER database 20102013. Oncotarget. 2017 Jan 3; 8(1): 345-353. https://doi.org/10.18632/oncotarget.13395

9. Pacini MG, Castagna L, Brilli G, Pentheroudakis G, On behalf of the ESMO Guidelines Working Group. Thyroid cancer: ESMO Clinical Practice Guidelines for diagnosis, treatment and follow-up. Annals of Oncology. 2010. 21: 214-9. https://doi.org/10.1093/annonc/mdq190

10. Shintyapina AB, Shevchenko SP. Epidemiological characteristics and evaluation of thyroid cancer risk factors in Novosibirsk. Siberian Cancer Journal. 2011; 1: 25-2 (in Russian).

11. www.reference.com/Statistics+For+Cancer [cited 2017 Dec 02]. 